\title{
Panama: Democracy under the Shadow of Corruption
}

\author{
Panamá: Democracia bajo la sombra de la corrupción
}

\section{ORLANDO J. PÉREZ}

Millersville University, USA

\begin{abstract}
In 2016 Panama was buffeted by corruption scandals and a decelerating economy, which had negative consequences for the political standing of President Juan Carlos Varela. The "Panama Papers" revealed the underlying pathology in Panama's political and economic system. After a decade of rapid economic growth, Panama's economy showed signs of slowing down. However, the completion of the Panama Canal expansion project provided hope for an economic boost as the waterway was able to service a greater proportion of maritime commercial traffic.
\end{abstract}

Key Words: Panama, corruption, Panama Papers, Juan Carlos Varela, Panama Canal

\section{RESUMEN}

En el año 2016 Panamá fue azotada por escándalos de corrupción y una economía en desaceleración que tuvo consecuencias negativas en la posición politica del Presidente Juan Carlos Varela. Los "Papeles de Panamá" revelaron la patología subyacente en el sistema político y económico de Panamá. Tras una década de rápido crecimiento la economía panameña mostró signos de desaceleración. Sin embargo, la terminación del proyecto de ampliación del Canal de Panamá genera un impulso económico en la medida que la vía marítima puede servir una mayor proporción de tráfico comercial.

Palabras clave: Panamá, corrupción, Los Papeles de Panamá, Juan Carlos Varela, Canal de Panamá 


\section{INTRODUCTION}

In 2016 Panamanian President Juan Carlos Varela marked two years into his five-year term. Corruption, the completion of the Panama Canal expansion, and a weakening of economic growth were the key factors shaping the political environment in Panama. The inability to restrain corrupt practices is perhaps the most significant weakness of Panama's political system. Panama ranked 87th out of 176 countries and territories surveyed in Transparency International's 2016 Corruption Perceptions Index (Transparency International 2017). Major corruption cases involved the financial services industry, government procurement, and the judicial system.

The revelations in the "Panama Papers" focused world attention on Panama's financial and commercial systems. The "Panama Papers" showed how a Panamanian law firm helped set up more than 200,000 shell corporations, many of them used by corrupt politicians, criminals and tax abusers around the world. The law firm, Mossack Fonseca, is just one of hundreds of law firms that provide services that can be used to enable corruption, illicit financial transactions, drug trafficking, terrorism, tax evasion and the surge in economic inequality. Panama's low tax environment and open economy, combined with its sophisticated banking system, provide the perfect platform for avoiding taxation or cleaning illicit gains.

Panama is a transactional society. The country has been characterized as the nation of the "deal." A colloquial expression, juega vivo, captures the essence of a culture in which exploiting every angle to gain an advantage is seen as normal. While this behavior is a natural outgrowth of a society in which overcoming scarcity often demands pursuing opportunities, in the context of a modern economy it can degenerate into corrupt practices. Viewed from this perspective the "Panama Papers," and the activities they represent, can be seen as a manifestation of juega vivo on a grand scale (Pérez 2012, 2017).

Another driver of corruption is inequality. Panama continues to be one of Latin America's most unequal countries. Panama's Gini Index of Per Capita Household Income is 51.9, which is much higher than any country in Asia and double in average than the figures found in developed countries. Another factor is a legacy of clientelism that continues to shape citizens' relations with the state. Over half of Panamanians believe that personal interest is one of the key drivers of behavior and over 80 percent respectively believe that individual criteria guide decision in public administration (CNTCC 2009). Finally, weak institutional accountability also encourages corruption.

\section{SOCIAL AND ECONOMIC CONDITIONS}

Panama has a population of around four million people living in 10 provinces, 75 districts or municipalities, five collective and semi-autonomous Indigenous 
territories organized by ethnic groups (comarcas), and 620 corregimientos (the smallest political unit). Panama is home to eight Indigenous ethnic groups, namely the Ngäbe Buglé $(260,058)$, Kuna or Guna $(80,526)$, Emberá $(31,284)$, Buglé $(24,912)$, Wounaan $(7,279)$, Teribe/Naso $(4,046)$, Bokota $(1,959)$, and Bribri $(1,068)$. The 2010 census shows that 196,059 indigenous persons live in comarcas, while 221,500 live in other areas. The comarcas and other indigenous territories enjoy significant autonomy and self-government through 10 Congresses and two Councils. The comarcas make up 22.2 percent of the country's area, or 16,634 square kilometers, and comprise some of Panama's richest natural resources and cultural diversity. Panama is also home to a population of Afro-descendants, which comprised 9.2 percent of the national population in 2010. The majority of Afro-Panamanians live in Colón (29 percent), Darién (17 percent), and Panama City (11 percent).

Panama has made significant progress in reducing poverty in recent years. Between 2008 and 2014, Panama managed to reduce poverty from 26.2 percent to 18.7 percent, and extreme poverty from 14.5 percent to 10.2 percent. This means that, of a population of about 3.9 million people, an additional 168,000 Panamanians overcame extreme poverty while close to 300,000 got out of poverty during that period (Koehler-Geib et al. 2015). Despite this progress, sharp regional disparities remain. Poverty prevails in rural areas, mainly inhabited by indigenous people. While in urban areas extreme poverty is below 4 percent, in rural areas it is about 27 percent. Moreover, in contrast to urban areas, where poverty has fallen every year since 2007, extreme poverty levels have fluctuated in rural areas. For example, the Ngäbe Buglé comarca has a poverty rate of 93 percent and an extreme poverty rate of 80 percent. Lack of services, particularly access to water, sanitation, and health care continues to be a constraint in the comarcas. The poverty rates in indigenous communities surpass those among indigenous peoples in other countries including Bolivia, Ecuador, Guatemala, and Peru (Economic Commission for Latin America and the Caribbean (ECLAC) 2014).

In the beginning of 2016, the Economy and Finance Ministry (MEF) predicted that the growth of the country's Gross Domestic Product (GDP) would peak at $6.3 \%$ before revising this prognosis to $6.2 \%$, then $5.6 \%$, and finally $5.2 \%$ growth at the year's end. While the $5.2 \%$ growth is the lowest in 5 years, it still left Panama with the second highest growth rate in Latin America. The highest growth rates were in construction and mining and quarrying (9.4\% in both cases), chiefly driven by public infrastructure projects including Line 2 of the Panama City Metro (the metropolitan railway system of the country's capital), water supply and sanitation projects and ongoing construction of power transmission lines. The inflation rate stood at $1.5 \%$, similar to the rate recorded in 2015 , while unemployment rose $0.6 \%$ to $6.4 \%$ (ECLAC 2016). 
Table 1. Panama: main economic indicators, 2014-2016

\begin{tabular}{lccc}
\hline & 2014 & 2015 & 2016 \\
\hline Gross domestic product & & \multicolumn{2}{c}{ Annual growth rate } \\
Per capita gross domestic product & 6.1 & 5.8 & 5.2 \\
Consumer prices & 4.4 & 4.1 & 3.6 \\
\hline & 1.0 & 0.3 & 1.2 \\
\hline Urban unemployment rate & & Annual average percentage \\
Central government overall balance / GDP & 5.4 & 5.8 & 6.4 \\
\hline & -4.0 & -3.9 & -2.9 \\
\hline Exports of goods and services & & \multicolumn{2}{c}{ Millions of dollars } \\
Imports of goods and services & 27,626 & 27,319 & 25,674 \\
Current account balance & 30,663 & 26,991 & 24,157 \\
\hline
\end{tabular}

Source: Economic Commission for Latin America and the Caribbean

One of the areas of the economy that suffered in 2016 was the Colón Free Trade Zone. The association of users of the zone (Asociación de Usarios de la Zona Libre de Colón) reported that 55 companies had closed in January 2016 alone, in addition to the 125 businesses that ceased to operate in 2015 (Guía 2016, 18 February). According to a report by Panama's Finance and Economy Ministry (MEF), reexports in the zone reached US\$10.52bn in the first 11 months of 2015, down $13.7 \%$ on the same period in 2014. The same MEF report shows that sales to Venezuela dropped by $37.3 \%$ in $2013,15.7 \%$ in 2014 , and $49.2 \%$ in 2015 . Sales to Colombia dropped by $3.2 \%$ in 2014 and $25.2 \%$ in 2015 (Ministerio de Economía y Finanzas 2016).

The trade problems with Venezuela and Colombia began under the previous government led by President Ricardo Martinelli (2009-2014). Venezuelan companies failed to pay off debts to the free trade zone-a situation attributed to Venezuela's foreign currency controls, which restrict the supply of US dollars available to Venezuelan companies for trading purposes (Molina 2016, 24 April). The dispute with Colombia stems from a March 2013 decree issued by President Juan Manuel Santos which introduced a temporary (12 month) ad valorem duty of $10 \%$ and a specific duty of US $\$ 5$ per gross kilogram on all imports of apparel and footwear from countries with which Colombia does not have a Free Trade Agreement (FTA). These duties affected Panamanian exports because, although both countries signed an FTA in September 2013, the agreement has yet to be ratified by their respective legislatures. Panama won a complaint against the tariff with the World Trade Organization (WTO) in November 2015, but Colombia appealed the decision in January 2016 (Sanz 2016, 13 September). On 23 March 2016, the legislature approved a law updating the legal framework for the Colón Free Trade Zone. The changes included fiscal benefits for users and a reduction of bureaucracy aimed at making the zone more competitive 
(EFE 2016, 23 March). The legislature also established a special free port system for Colón City, which, among other things, creates a shopping area in the city's downtown and introduces changes to boost tourism and trade (EFE 2016, 14 March).

One of the positive notes of the year was the completion of the Panama Canal expansion project. At a ceremony on 26 June, the container vessel "Andronikos" of the China Ocean Shipping Company became the first ship to transit the expanded Canal. The Panama Canal Authority calculates that in the first fiscal year after the Canal expansion, revenues will increase by $40 \%$ to US\$1.4bn. By 2021, it is estimated that revenues will grow to US\$2.1bn or $2.8 \%$ of GDP. ECLAC noted the positive impact of the Canal expansion on other indicators such as foreign direct investment (FDI). A June 2016 ECLAC report on FDI to the region notes that in 2015 FDI flows to Panama rose by $17 \%$ to reach US\$5.04bn - a record high, positioning the country as the leading recipient in Central America, and seventh in Latin America and the Caribbean. The ECLAC report noted that "during 2016, the work of widening the Panama Canal will be completed and a number of firms involved in Canal-related activities have made major investments to expand their capacities." Expansion is expected to result in a $40 \%$ increase in investment in the logistics sector, create between $150,000-250,000$ jobs by 2026, and boost Canal contributions to state coffers by $45 \%$ by the beginning of 2017 (ECLAC 2016). Because of the Canal expansion and other developments, Panama has a different and more diversified economy than other commodity export-dependent Latin American nations. According to the World Bank (2016), "Panama continues to be an attractive country for foreign direct investment. The prospects of sustained high growth are also supported by emerging opportunities in transport and logistics, mining, financial services, and tourism."

Initial indications suggest that canal traffic has increased but the shipping industry remains volatile; maritime commercial demand is fluctuating as intermodal land transportation and other waterways, such as the Suez Canal, become more competitive vis-à-vis the Panama route. The Panama Canal Authority expects a US\$263.6 million increase in toll revenue in fiscal 2017, and says its total contribution to the Panamanian treasury will rise in that year to US\$1.6bn, up from US\$1bn in fiscal 2016. According to the national statistics institute (INEC), second quarter 2016 toll revenues were down 8.7\% over the same period in 2015, while revenues from related services to shipping were off by $13.1 \%$ (PMC Asset Management 2016).

Finally, in a sign that Panama's economy remains competitive, the World Economic Forum's Global Competitiveness Report 2016-2017 reported that Panama had improved eight places in the rankings since the previous report for 2015-16, securing its position as the 42nd most competitive economy in a global ranking. It is only surpassed in Latin America by Chile. The report judges national economies based on 12 factors that promote competitiveness: institutions and infrastructure, health, primary and university education, 
market efficiency, labor market efficiency, technological advances, market size, development of the financial market, business sophistication and innovation (Schwab 2016).

\section{POLITICAL CONDITIONS}

Twenty-seven years after a military invasion by the United States that ousted General Manuel Noriega from power, Panama's political system has made significant strides toward establishing a functional democratic regime. Five free and competitive presidential elections, all won by the opposition, have solidified the country's electoral system. A successful demilitarization process transformed the politicized and powerful Panamanian Defense Forces into a civilian-controlled national police. The transfer of the Panama Canal and its successful management established sovereignty over the country's most important asset (see Pérez 2011). Furthermore, investment in infrastructure projects such as the expansion of the Panama Canal has led to a decade of extraordinary economic growth. However, problems such as corruption, weak and inefficient judicial institutions, and the unequal distribution of economic growth remain as significant impediments to democratic consolidation (see Guevara-Mann 2008, 2016; Luna and Sánchez 2009; Gandásegui 2010; Brown and Luna 2013).

In 2016, Panama's politics were characterized by conflict and charges of corruption in the selection of justices to the Supreme Court and declining approval ratings for President Juan Carlos Varela. In January, President Juan Carlos Varela swore in two new magistrates for the nine-member Supreme Court (CSJ) for the period 2016-2025 (Moreno 2016, 4 January). The appointments come as Panama's judiciary is under scrutiny following recent charges of corruption by several members, as well as ongoing efforts to bring former President Ricardo Martinelli (2009-2014) to justice.

Selected from a shortlist of ten drawn up by an ad-hoc executive commission (comprising Ministers of the Presidency and Interior, Álvaro Alemán and Milton Henríquez, respectively, and presidential advisor Francisco Sierra), the new justices are Ángela Russo Maineri de Cedeño and Cecilio Antonio Cedalise Riquelme. Russo is an attorney in private practice who teaches family law at the Universidad Católica Santa María La Antigua (USMA), while Cedalise is a labor lawyer who served as one of Panama's negotiators for the US-Panama Trade Promotion Agreement (TPA) and has advised the Ministry of Labor and teaches labor law at several universities (La Estrella de Panamá 2015, 21 December). The two new magistrates replaced Harley Mitchell and Nelly Cedeño. The latter was an alternate for Víctor Benavides, who was forced to step down as CSJ magistrate in 2015 for alleged illicit enrichment and sexual crimes against minors. Benavides was the second CSJ magistrate to resign since former CSJ president, Alejandro Moncada Luna, quit in 2014, also over corruption 
allegations (Guía 2015, 19 June). In an unprecedented move, in March 2015 Moncada Luna received a five-year prison sentence for illicit enrichment and falsifying documents (La Prensa 2015, 5 March).

Concerns over the selection of Supreme Court justices were fueled not just by the Benavides and Moncada Luna cases but also the dismantling of a corruption ring within the judiciary in November 2015 in which 13 people, including judicial officers, were arrested for improper negotiation of bail agreements, the withholding of arrest warrants, manipulation of hearing dates, and the bribing of jurors (La Crítica 2015, 13 November).

Another scandal that attracted widespread criticism was the re-election of José Ayú Prado as president of the Supreme Court for the period 2016-2017. Ayú Prado had been attorney general (2011-2013) under President Martinelli and his original nomination to the court was widely criticized by civil society groups. Shortly after being named president of the court, magistrate Harry Díaz, whom Ayú Prado defeated to win the CSJ presidency, made a number of allegations against both his colleague and former President Martinelli, whom he accused of interfering in court decisions. The allegations, which Díaz made in an interview with local media Telemetro, included claims that Martinelli had put pressure on him to pick another CSJ magistrate, Luis Ramón Fábrega, as the CSJ's vicepresident (La Prensa 2016, 14 January).

Corruption charges against former President Martinelli continued to garner headlines during 2016. The former president fled Panama for the United States shortly after the 2014 elections because of several scandals related to (1) his use of state resources to spy on political enemies and (2) embezzlement of funds from the National Assistance Program (PAN), a highly touted welfare program started during Martinelli's administration. The investigation centers on allegations that government officials inflated contracts and took bribes to favor certain suppliers. Two former PAN Directors have been arrested for allegedly skimming $\$ 60$ million dollars from contracts. Prosecutors have indicted 120 people and seized $\$ 22$ million dollars in connection with the case. More than a billion dollars in contracts issued between 2010 and 2014 have come under close scrutiny due to poor accounting records (Wilkinson 2015, 23 May; Prieto-Barreiro 2015, 19 August). In early 2015, the Supreme Court of Panama lifted the immunity from prosecution of the former president and named a special prosecutor to investigate the charges. In July 2016, the court asked the foreign ministry to request the president's extradition from the United States. In September 2016, the Panamanian foreign ministry delivered the extradition request to the US Department of State. As of early 2017, Martinelli was still fighting extradition, alleging political persecution by the Panamanian government (Schmidt 2017, 21 March). 


\section{THE "PANAMA PAPERS"}

The most significant and far reaching corruption case surrounded the socalled "Panama Papers." The result of a year-long investigation by the German newspaper Süddeutsche Zeitung, the International Consortium of Investigative Journalists (ICIJ) and over 100 other news organizations, the "Panama Papers" were released on 3 April. The documents show how secretly-owned companies are an important vehicle for corruption that facilitates the secret movements of money and other activity away from the eyes of law enforcement, tax collectors, and regulators. The files contain information on more than 200,000 offshore entities connected to people in more than 200 countries and territories (ICIJ n.d.). The documents revealed the operations of Mossack Fonseca, the world's fourth biggest offshore law firm based in Panama. The firm runs a worldwide operation. Its website boasts of a global network with 600 people working in 42 countries. It has franchises around the world, where separately-owned affiliates sign up new customers and have exclusive rights to use its brand. Mossack Fonseca operates in tax havens including Switzerland, Cyprus and the British Virgin Islands, and in the British crown dependencies Guernsey, Jersey and the Isle of Man. The documents show the myriad ways in which wealthy entrepreneurs, politicians and drug traffickers can exploit secretive offshore tax regimes to hide money and avoid taxes.

The "Panama Papers" revealed the extent to which Panama's economy depends on the banking and financial services sector. Panama's status as a tax haven began in 1919 with the registry of foreign ships to help Standard Oil escape U.S. taxes and regulations. The shipping registry was designed to minimize taxes, regulations and disclosure requirements in order to attract foreign owners wanting to escape their home jurisdictions. U.S. ship owners wishing to sell alcohol to passengers used Panama's registry to avoid prohibition. The registry grew after World War II as ship companies sought to avoid higher wages and improved working conditions mandated by U.S. law. Before that, JP Morgan had helped Panama introduce incorporation laws in 1927 that permitted anyone to start tax-free, anonymous corporations, thus paving the way for its role in offshore finance. In 1970, Panama established the National Banking Commission and laid the foundation for the country's banking and financial center. To attract offshore investments, the decree forbade the investigation of the private affairs of any bank client except under a court order. In 1970 there were 21 banks with assets of $\$ 898$ million; by 1982 Panama had 125 banks with assets of $\$ 49$ billion. Another benefit of Panama's system was the popularity of "bearer shares" stock certificates without a designated owner. The provision effectively allowed for anonymous ownership of a corporation. By the 1980s, Panama's dollarized economy, secrecy laws, low tax environment, and substantial commercial links to the United States had become a magnet for those who sought to launder illicit capital and traffic drugs across the world. After the U.S. invasion of 1989, confidence in Panama's financial services industry returned, and by 2015 the 
system reported $\$ 118$ billion in assets, close to $\$ 10$ billion more than in 2014 . Today, financial services make up about $8 \%$ of Panama's GDP.

In the past 5 years, under pressure from the United States and other international organizations, Panama has signed a number of tax and information exchange treaties that have increased the transparency of the system. However, foreign governments and international law enforcement agencies still have to obtain a court order before banking data can be disclosed. In 2015, the country moved to regulate bearer shares to minimize anonymity and increase transparency. The new regulations were a result of international demands that Panama comply with the standards set by the OECD Global Forum on Transparency and the recommendations of the Financial Action Task Force (FATF). Despite these positive steps, many Panamanians are wary of the impact that additional compliance will have on the lucrative financial services industry. Some see the latest revelations in the "Panama Papers" as an attempt to smear the "good" name of the country and undermine its growing economy.

Shortly after the release of the documents, the OECD called on Panama to "immediately implement" international tax transparency standards. The OECD also cast doubt on Panama's commitment to fiscal transparency, recalling that "just a few weeks ago we told G20 Finance Ministers that Panama was back-tracking on its commitment to automatic exchange of financial account information" (OECD 2016a; Wolters Kluwer 2016, 20 April). The OECD statement was referring to a report released at the end of February 2016 to G-20 finance ministers by the Global Forum on Transparency and Exchange of Information. According to the report, in November 2015 the Global Forum reported that Panama had committed to the new international standard on Automatic Exchange of Information (AEOI) but "this is no longer the case." The same report noted that "the Global Forum has engaged extensively with Panama but it has been made clear that Panama cannot commit to the Standard on par with the rest of the committed jurisdictions" (OECD 2016b, 21).

The involvement of Mossack Fonseca touched President Varela's political inner circle. Juan Ramón Fonseca, a partner at the law firm, was minister without portfolio in the Varela administration, a post he had held since July 2014, as well as president of the Partido Panameñista (PPA). Juan Ramón Fonseca's influence extended to his son, Eduardo Fonseca Ward (Panama's general consul in Dubai and the United Arab Emirates), and brother, Alfredo Fonseca Mora (the director of the civil aviation authority) (Pérez 2016, 5 April).

President Varela complained that Panama was being scapegoated. The day after the leak, President Varela issued a press release in which he defended his government's actions to comply with international standards of transparency and accountability for the banking and financial services sectors. He pointed to the February 2016 decision by the Paris-based Financial Action Task Force (FATF), the international organization dedicated to combating money laundering, to remove Panama from its "grey list" of countries with inadequate 
provisions in place to combat money laundering and financing of terrorism. In the same press release, President Varela also said that in January 2016, new rules took effect limiting the use of bearer shares in the country (Justice 2016, 5 April). President Varela also announced that the government would set up an independent committee of national and international experts to evaluate current working practices and propose new measures aimed at strengthening the transparency of the national financial and legal systems (BBC 2016, 7 April). The Panamanian government also contracted Bellwether Strategies to "promote Panama's commercial and diplomatic objectives" and to provide centralized "crisis communication" strategies for the government's response to the Panama Papers.

The presidential commission was composed of Nobel Prize-winner in economics, Joseph Stiglitz; Mark Pieth, Professor of Criminology at University of Basil; Roberto Artavia, Dean of the School of Business at INCAE; Gisela Álvarez de Porras, former Minister of Commerce and Industries; Alberto Alemán Zubieta, former administrator of the Panama Canal; Domingo Latorraca, partner at Deloitte; and Nicolás Ardito Barletta, former President of Panama (Gobierno de la República de Panamá 2016, 20 April). The commission's work was controversial from the start as pressures on how much information would be made public and the extent of the reforms it would advocate divided the members. In early August, in a blow to President Varela, the commission's co-chair, Joseph Stiglitz, and Swiss expert Mark Pieth resigned citing a lack of transparency and disputes over the handling of the commission's findings. Stiglitz was quoted as saying "I thought the government was more committed [to making the report public], but obviously they're not...It's amazing how they tried to undermine us" (Reuters 2016, 6 August).

The commission's report was finally released on November 21, 2016. Among the recommendations, the 23-page report urged the government to:

"establish as soon as possible an integral vision for the national strategy of international services, which must respond to the national interest and to the national strategy of long-term development. Specifically, this should include Panama's exclusion from any discriminatory list related to tax issues, transparency and effective exchange of information as one of its main objectives. The strategy should define short-, medium- and long-term initiatives to ensure compliance with this strategic objective based on the recommendations made below and on a constant analysis of trends and risks in the international context" (14).

The report also called for the creation of an independent, permanent committee of legal and financial experts to ensure that its recommendations were implemented (Committee of Independent Experts 2016; Fitzgibbon 2016, 21 November). 
The situation worsened in May with the U.S. designation of a group of Panamabased companies as money laundering operation and their heads, Nidal Ahmed Waked Hatum and Abdul Mohamed Waked Fares, as Specially Designated Narcotics Traffickers pursuant to the Foreign Narcotics Kingpin Designation Act (Kingpin Act) (Department of Treasury 2016). The Waked family controls some of Panama's most important business holdings, with interests in real estate, banks, media, retail and a re-export operation in the Colón Free Trade Zone. The designation came the day after Waked Hatum - described by the US Drug Enforcement Administration (DEA) as "one of the world's biggest drug money launderers" - was arrested in Colombia by local police, after being charged in the US's Southern District of Florida with money laundering and bank fraud (BBC 2016, 7 May; Department of Justice 2016). The Waked group apparently used a series of more than 60 companies involved in real estate, construction, banking, hospitality and media (including two leading newspapers La Estrella de Panama and El Siglo) to launder drug-related money.

The Waked designation came at an awkward moment for President Varela when he was in Washington DC attending the 46th Annual Washington Conference on the Americas, co-hosted by the U.S. State Department and Council of the Americas. On that visit, Varela assured the world that "Panama's success does not depend on irregular flows of money into our financial system [but] is based on the hard work of the Panamanian people." He pointed to recent moves like the establishment of a local panel of experts to look at the financial services system and new tax information sharing deals such as an Intergovernmental Agreement (IGA) with the United States to implement the Foreign Account Tax Compliance Act (FATCA) (Varela, Juan Carlos. 2016, 3 May).

In the midst of the scandal, President Varela had to protect nearly 6,000 jobs in companies affiliated to the Waked Group. Under U.S. regulations, when a foreign citizen or company is listed as a money laundering organization all U.S. citizens and corporations must cease doing business with it. This means that the future of many Panamanian companies owned by the Waked family is now at risk (Semana 2016, 9 May).

President Varela scrambled to restore Panama's credibility. On 17 May 2016, an official delegation headed up by Panama's Deputy Foreign Minister, Luis Miguel Hincapié, travelled to Paris to meet representatives from the Organization for Economic Co-operation and Development (OECD) and discuss financial transparency-related issues. Following the meeting, the foreign ministry announced that starting in 2018 the Panamanian government will begin implementing the Common Reporting Standard (CRS) of the OECD Global Forum through bilateral agreements. According to a Panamanian foreign ministry press release, the OECD agreed to offer "all the necessary technical assistance for the implementation of new laws and technological systems required by the automatic exchange of information" (La Prensa 2016, 18 May). 


\section{PUBLIC POLICY}

In July, President Varela unveiled the 2017 budget, which forecasts GDP growth of $6 \%$ and inflation of $1.1 \%$. Economy and Finance Minister Dulcidio De La Guardia said that the proposed budget contemplated US\$5.148 billion for investment in the non-financial sector, of which US $\$ 2.407 \mathrm{bn}$ was for infrastructure projects including an extension of lines one and two of the Panama City metro, as well as construction of line three; regeneration of Colón City; construction of a fourth bridge over the Panama Canal; basic sanitation projects and road infrastructure projects, among other things. Crucially, the draft budget earmarked US\$330 million for an increase in salaries for teachers, health care providers and law enforcement officials. The increased salaries came in the midst of widespread teacher protests. Panama's umbrella teachers' union, Unión Nacional de Educadores Panameños (UNEP) staged a nationwide strike in demand of higher salaries and more spending on education. The strike was called-off after six days following a deal struck between UNEP and the government whereby teachers will receive a monthly increase of US\$300 beginning July 2017.

The teachers' unrest came as President Varela continued to struggle with poor approval ratings. According to pollster Dichter \& Neira, his approval was just $40 \%$ in June, up from $37 \%$ the previous month, which had been his lowest rating of the past 12 months. The President's approval ratings had been in the 80 percent range during his first 100 days in government. The same Dichter \& Neira survey showed that just $20 \%$ of respondents thought that public education was improving under the current administration, down from $27 \%$ in June 2015. Meanwhile, insecurity continued to be named as the major problem facing the country, cited by $21 \%$ of respondents, ahead of the cost of living (20\%) and unemployment (12\%) (Dichter \& Neira 2016a). The November 2016 survey by Dichter \& Neira, released on November 22, showed President Varela with $42 \%$ approval, up from 39\% in October and $40 \%$ in September. However, the same survey showed that just $15 \%$ of respondents believed that the government operated in a transparent manner (Dichter \& Neira 2016b, 2016c, 2016d).

Relations with indigenous groups remained tense as President Varela sought to reach an agreement with the Ngäbe Buglé indigenous comarca to build the "Barro Blanco" hydroelectric dam. The project, which began in 2011 and is almost complete, remained controversial, with the Ngäbe Buglé community complaining that it would displace thousands of local inhabitants and they had not been properly consulted about the initiative prior to its launch (Center for International Environmental Law 2016). The project was suspended in February 2015 after the government determined that certain environmental requirements had not been met. Negotiations between the government and indigenous leaders have been taking place ever since.

In August 2016, President Varela hailed a deal with the Ngäbe Buglé indigenous comarca that would have allowed the completion of the dam. The deal includes a stipulation that $50 \%$ of all personnel employed in the project must be indigenous 
and campesinos from the comarca. Other points include the establishment of a trust fund with government contributions to promote local agriculture, fishing, forestry, eco-tourism and artisanal sectors, personnel training, and rural electrification in surrounding communities. The government also agreed to annul existing hydroelectric concessions on the Tabasará River and pledged that future concessions in the Ngäbe Buglé comarca would be approved by the local population through a referendum and local, regional and general congresses (Gobierno de la República de Panamá 2016, 22 August).

Opposition to the agreement was swift. The Ngäbe Buglé general congress rejected the agreement on September 2016 (León 2016, 18 September). The move by the Ngäbe Buglé congress, which the previous day also dismissed its chief Silvia Carrera, one of the deal's signatories, was a major setback for President Varela (La Prensa 2016, 17 September).

Crime and insecurity were important issues during 2016. On 3 October, the security ministry published figures which showed that from January to September 2016, 304 homicides were registered nationwide, down from 374 over the same period in 2015. The report also showed that in the past three years, the national homicide rate fell from 16.1 per 100,000 inhabitants in 2014, to 12.4 in 2015 and 7.5 in 2016 (La Estrella de Panamá 2016, 22 December). As regards drug seizures, official figures released by the ministry in October showed that 50 tons of drugs were confiscated and over 1,500 people arrested in anti-drug operations by the National Police, the border service (SENAFRONT), and national air service (SENAN). According to the Ministry of Security, the National Police confiscated 26.5 tons of illegal drugs, with SENAN and SENAFRONT confiscating 21.5 and 2.3 tons, respectively (El Panamá América 2016, 20 October).

In July President Varela announced the creation of a new special antinarcotics force (Fuerza Especial Antinarcóticos, FEAN) (La Prensa 2016, 25 July). This followed the release of a report by the United Nations Office on Drugs and Crime (UNODC) on Colombia which confirmed that there was a significant increase in coca plantation areas (and potential cocaine production in Colombia in 2015) from 2014 to 2015 (Oficina de las Naciones Unidas para la Droga y el Delito 2016). The new force followed a series of high-level operations during 2015 by specialized joint task forces of the National Police, SENAFRONT, SENAN and the Institutional Protection Service (SIP).

While the government focused on extending security measures, a number of corruption cases surfaced involving the national police and the prison system. Panama's Interior Minister, Milton Henríquez, announced the dismantling of a corruption ring in the country's prisons, resulting in 13 arrests, including four officials and three former officials from the prison service. An interior ministry press release stated that the operation was carried out by the public ministry (attorney general), the National Police, the general inspectorate of prisons, and the directorate of judicial investigations. According to the press release, 
the corruption ring, which had been operating for various years, had altered judicial sentences and manipulated the transfer of inmates from one prison to another, among other things (Mendoza 2016, 11 August).

Finally, in September the government announced the implementation of a new legal system based on the adversarial approach (where two advocates represent their parties' positions before a jury or judge), ending a process that began in 2011. The new system replaces the inquisitorial system, where the courts are actively involved in investigating the facts of the case. The United Nations Office on Drugs and Crime (UNODC), which provided assistance during the transition process, highlighted the expectation that the new system "will allow for a speedier and more transparent resolution of conflicts between parties" (UNODC 2016).

\section{EXECUTIVE BRANCH}

The President of Panama is the head of state and government and is elected by popular vote (FPTP) for a five-year term. Outgoing presidents may not hold the office for the two terms immediately following their presidency. President Juan Carlos Varela's government has suffered a massive decline in approval ratings in the two years since coming to power. An accumulation of corruption cases and the inability or unwillingness to promote promised legal and constitutional changes have eroded Varela's standing with the public. The ability to exploit divisions in rival parties and to cobble together majorities in parliament has prevented the situation from getting worse. Continued economic expansion, albeit slower than in 2015, and investment in major infrastructure projects have also contributed to keeping the president's approval ratings from dropping even further.

Table 2 lists the ministries and ministers at the end of 2016. Eight of fifteen ministries are headed by technocrats or politically independent ministers. Four ministries are held by members of the president's party, and one was occupiedat least until December 2016 - by a member of the coalition's junior partner, the Partido Popular. 
Table 2. Executive Branch Ministries

\begin{tabular}{lcc}
\hline \multicolumn{1}{c}{ Ministry } & Name & Party Affiliation \\
\hline Interior & Milton Henriquez & Partido Popular \\
Vice-President \& Foreign Relations & Isabel Saint Malo & Independent \\
Economy \& Finance & Dulcidio de la Guardia & Panameñista \\
Panama Canal & Roberto Roy & \\
Commerce \& Industry & Augusto Arosemena Moreno & Independent \\
Education & Marcela Paredes de Vásquez & Independent \\
Housing \& Territorial Coordination & Marío Etchelecu & Panameñista \\
Presidency & Álvaro Alemán & Panameñista \\
Public Works & Ramón Arosemena & Independent \\
Public Security & Alexis Betancourt Yau & Independent \\
Agriculture & Eduardo Enrique Carles & Independent \\
Health & Miguel Mayo & Independent \\
Work \& Labor Development & Luis Ernesto Carles & Panameñista \\
Environment & Mirei Endara & Independent \\
Social Development & Alcibíades Vásquez Velásquez & Panameñista \\
\hline
\end{tabular}

Source: Elaboration by author based on ministry webpages and news reports.

A power struggle within the Ministry of Security led to the forced resignation of the minister, Rodolfo Aguilera, and his deputy, Rogelio Donadío. President Juan Carlos Varela then named Alexis Bethancourt Yau to the position. While the two officials had bickered over internal ministry operations for over a year, the final straw came with reports that in October 2015 Donadio had handcuffed a ministry official, Carlos López, and questioned him over irregularities while dressed in a uniform of the national border service. Donadio did not have the authority to detain nor question the official (Guía 2016, 5 May).

The new security minister, Alexis Bethancourt Yau, has worked with the ministries of the presidency and economy and finance, as well as the Presidential Commission for the Defense of the International Financial Services (CANDSIF), an advisory committee set up in 2009 by then president Martín Torrijos (20042009) to strengthen transparency efforts. He also played a key role in Panama's removal from the Paris-based Financial Action Task Force (FATF)'s "grey list." The departure of Rodolfo Aguilera and Rogelio Donadío was received well by civil society groups, who argued that the power struggle between the two men was damaging the government's anti-crime efforts.

Another significant change in the cabinet occurred in December 2016 when Milton Henriquez formerly Minister of the Interior, was reassigned to become Panama's ambassador to Spain. Henriquez was the only member of the ruling coalition's junior partner, the Partido Popular (Popular Party), to hold a ministerial position. 


\section{VII.LEGISLATIVE BRANCH}

The National Assembly (Asamblea Nacional) is Panama's unicameral legislature, composed of 71 deputies elected in single or multi-member constituencies, called circuitos electorales. These electoral constituencies are based on Panama's administrative districts, which are the second-level administrative divisions: each district with a population over 40,000 inhabitants forms a constituency on its own, and each constituency elects one deputy per 30,000 inhabitants and an additional one for every fraction over 10,000. There are 26 single-member constituencies whose members are elected by first-pass-the-post. The remaining 13 constituencies elect between two and seven deputies, returning a total of 45 deputies. In multi-member constituencies, voters vote for only one candidate on the party's list. Seats are attributed using an electoral quotient, which is the number of valid votes cast divided by the number of seats to be filled. Party lists that have obtained more votes than the quotient obtain as many seats as they have full quotients. In the event that no party has won more votes than the quotient or there are still seats left to be filled, seats are distributed to parties that have obtained more than half of the quotient (medio cociente); parties that have already won seats with the quotient are not eligible for seats. Finally, if there are any seats left to be filled, they are distributed to candidates with the highest votes.

Table 3 shows the distribution of seats in the National Assembly for the period 2014-2019. While the president's party, Partido Panameñista (PA), does not have a majority in the Assembly, Panama's political system gives the president substantial power to forge cross-party alliances by using the powers of the executive to distribute subsidies and government contracts. The president's party forged an alliance with the PRD and a faction of the Cambio Democrático (CD) in order to control the Assembly. The current President of the Assembly is Yanibel Orrego Smith of the CD, along with First Vice-President Jorge Iván Arrocha (Panameñista) and Second Vice-President Gabriel Soto Martínez (Panameñista). According to the Latin American Network of Legislative Transparency, Panama's legislature is among the five least transparent in the region (Red Latinoamericana para la Transparencia Legislativa 2016). The report highlights the lack of clear public information about the procedural workings of the legislature and the informality of many of the rules that govern the behavior of the institution as well as its members. The report argues that institutional rules are often at the mercy of the president and vice-presidents of the Assembly, who normally serve a one year term. In a poll conducted in October 2016 by Dichter $\&$ Neira, only $27 \%$ of respondents sad the work of the legislature was excellent or good, with $65 \%$ saying it was bad or very bad (Dichter \& Neira. 2016c). 
Table 3. Legislative Branch (2014-2019)

\begin{tabular}{lc}
\hline \multicolumn{1}{c}{ Parties } & Number of Deputies \\
\hline Partido Panameñitas (PA) & 16 \\
Partido Revolucionario Democrático (PRD) & 25 \\
Partido Cambio Democrático (CD) & 26 \\
Partido MOLIRENA & 2 \\
Partido Popular (PP) & 1 \\
Independent & 1 \\
TOTAL & 71 \\
\hline
\end{tabular}

Source: http:/ /www.asamblea.gob.pa/

The constitution gives extensive legislative powers to the executive. In particular, the president has exclusive powers to formulate and introduce laws relating to the national budget (Article 264), wages (Article 153, Section 2), treaties and other international agreements (Article 153, Section 3), the creation of administrative departments (Article 153, Section 12), and finances and customs (Article 195, Section 7). In other words, in matters relating to the national economy and expenditure of funds the executive has been awarded exclusive legislative initiative. In matters of treaties and international agreements the legislature can only approve or disapprove the measure, and cannot make any changes to the proposed document. In the case of the national budget, if the legislature does not approve it by a certain date, the budget submitted by the executive becomes law without legislative action. This means that if the president does not want the legislature to change the budget, he or she can work with his or her allies in congress to block legislative action. This can occur particularly before an election when the president "packs" the budget with pork barrel projects to aid political allies and members of the same party.

The lack of budget initiative means legislators are at the mercy of the executive to satisfy constituent needs. Without significant powers to affect the national budget (probably the most important policy statement a government can make) the legislature cannot hope to become an active and effective branch of government.

The constitution gives the legislature certain powers vis-à-vis the executive. Article 153 establishes the following prerogatives of the National Assembly, including the ability to: approve, modify, or eliminate the National Codes (i.e., judicial, fiscal, civil, etc.); declare war and empower the executive to seek peace; declare amnesty for political crimes; establish or reform the territorial division of the nation; determine the weight, value, form, and type of the national currency; establish taxes and contributions to meet public services; set the general and specific norms to which all governmental entities must abide in relation to the negotiation of credit; organize the public debt; fix payment of the national debt; set and reform custom duties and taxes; determine-as proposed by the 
executive- the structure of the national government (i.e., the establishment or reform of ministries, autonomous agencies, etc.); and grant the executive the power to take extraordinary actions through decree when the assembly is not in session.

The prerogatives specified in Article 153 are tempered by the power of the executive to propose legislation. In fact, it is rare for congress to assert its right to initiate legislation on any of the matters mentioned in the article, particularly on those dealing with the economy. Given the weakness of the legislature, particularly with respect to resources, it seldom modifies laws proposed by the president or cabinet in a significant way. Furthermore, given the lack of support staff, most legislators do not exercise their individual prerogative of offering legislation. The legislature lacks an office of technical assistance that could evaluate executive branch proposals or assist legislators in the drafting of legislation. In most cases, the legislature relies entirely upon the technical expertise of particular ministries, thus creating a situation where the executive not only initiates legislation, but also provides the data to evaluate it. Legislators have little opportunity to gather independent advise on most measures.

The National Assembly does have a legal affairs office staffed by a few lawyers who give legal and, sometimes, technical advice on proposed legislation. The office, however, is grossly understaffed and lacks the personnel or capacity to give highly technical advice on complicated international or economic matters. The lack of resources affects the ability of the standing committees to perform oversight investigation on the behavior of the executive branch. Congressional committees have the power to call members of the executive to testify before them on any matter before the committee. However, they lack the staff and resources to perform the necessary investigation, or even ask the right questions. Each committee has only one or two staff members to advise legislators about issues within the jurisdiction of the committee.

\section{CONCLUSION}

In 2016 corruption was the primary challenge facing the administration of President Juan Carlos Varela. The "Panama Papers" revealed the underbelly of Panama's banking and financial services industry. The president's attempt to ameliorate the damage to Panama's reputation met with mixed results. Ironically, the independent commission President Varela named to provide recommendations on how to increase transparency within Panama's banking system degenerated into internal conflicts over issues of transparency. In the end, the commission's recommendations fell far short of what the international community had demanded. Corruption within the Supreme Court rocked the judicial system and revealed the lack of transparency and accountability in the naming of justices to the Supreme Court, and the significant influence the executive exercises over the judicial system. 
Panama's democracy has a number of assets and liabilities. The liabilities include problems with corruption. The very culture of transaction that promotes political compromise also promotes corrupt deal-making. Instrumental rationality dictates that "the ends justify the means," therefore, cheating, or as Panamanians say "juega vivo," generates a tendency to cut corners and do what is necessary to succeed, even if it means violating the rules. Executivelegislative relations are often dysfunctional and significantly weighted toward the executive. The legislative branch is fairly weak vis-à-vis the executive, and the quality of legislators leaves some to be desired. Political parties are generally weak and lack deep-rooted connections to social groups, and the ideological spectrum is narrow. Other problems include a weak and corrupt judicial system.

Despite these problems, however, Panamanians have been able to consolidate a system of free, fair and relatively competitive elections with an Electoral Tribunal that has generally performed well since 1990. Additionally, economic growth for the past decade has reduced poverty and created significant wealth that has permitted Panama to invest in significant infrastructure projects. The most important of these is the expansion of the Panama Canal, completed in June 2016, which will provide a boost to economic activity and ensure the viability of the waterway for decades to come. Inequality, however, remains a major problem, with rural and indigenous areas lagging significantly behind urban centers. The levels of inequality feed into corrupt practices and weaken democratic political culture.

\section{REFERENCES}

BBC. 2016, 7 April. “Panama Papers: Government Announces Creation of 'Panel of Experts.'” Retrieved from http://www.bbc.com/news/world-latin-america-35983950

BBC. 2016, 7 May. "'Money-launderer' Nidal Waked Arrested in Colombia." Retrieved from http://www.bbc.com/news/world-latin-america-36218993

Brown Araúz, Harry and Clara Inés Luna Vásquez. 2013. “Panamá: el crecimiento económico a expensas de la política." Revista de Ciencia Política 33(1): 287-301.

Center for International Environmental Law [CIEL]. 2016. “Barro Blanco Hydroelectric Dam Threatens Indigenous Communities, Panama." Retrieved from http://www.ciel.org/ project-update/barro-blanco/.

Committee of Independent Experts. 2016. Final Report. Retrieved from https://www.presidencia.gob.pa/tmp/file/1503/INDEPENDENT\%20EXPERT\%20COMMITTEE.pdf

Consejo Nacional de Transparencia contra la Corrupción [CNTCC]. 2009. Primer Estudio Exploratorio-Descriptivo sobre la Corrupción en Panama. Panama: CNTCC.

Department of Justice. 2016. "Panamanian National Arrested In Colombia For Money Laundering Conspiracy." Department of Justice, U.S. Attorney's Office, Southern District of Florida. Retrieved from https://www.justice.gov/usao-sdfl/pr/panamanian-national-arrested-colombia-money-laundering-conspiracy

Department of Treasury. 2016. "Treasury Sanctions the Waked Money Laundering Organization." Press Release. Retrieved from https://www.treasury.gov/press-center/ press-releases/Pages/j10450.aspx

Dichter \& Neira. 2016a. Encuesta de opinión pública, junio 2016. Retrieved from http:/ /www. dichter-neira.com/file/2016/07/Resultados-DNOP-junio-2016-VF-4-de-julio.pdf 
Dichter \& Neira. 2016b. Encuesta de opinión pública, noviembre 2016. Retrieved from http: / / www. dichter-neira.com / file/2016/11/Resultados-DNOP-noviembre-2016-Versión-Final-con-articulo-1.pdf.

Dichter \& Neira. 2016c. Encuesta de opinión pública, octubre 2016. Retrieved from http: / /www. dichter-neira.com/file/2016/10/Resultados-DNOP-octubre-2016-VF_con-articulo-1. pdf.

Dichter \& Neira. 2016d. Encuesta de opinión pública, septiembre 2016. Retrieved from http:// www.dichter-neira.com/file/2016/09/Resultados-DNOP-septiembre-2016-VF_ con-artículo.pdf.

ECLAC [Economic Commission for Latin America and the Caribbean]. 2014. Informe Los Pueblos Indígenas en América Latina. Avances en el último decenio y retos pendientes para la garantía de sus derechos. ECLAC: Santiago de Chile.

ECLAC [Economic Commission for Latin America and the Caribbean]. 2016. "Foreign Direct Investment in Latin America and the Caribbean 2016." Retrieved from http:/ / www. cepal.org/en/node/37450.

EFE. 2016, 14 March. "Parlamento de Panamá aprueba ley para convertir a Colón en 'puerto libre'." El Comercio. Retrieved from http:/ / www.elcomercio.com/actualidad/parlamento-panama-aprobacion-colon-puertolibre.html.

EFE. 2016, 23 March. "Parlamento panameño aprueba ley para aliviar crisis en Zona Libre de Colón." El Comercio. Retrieved from http:/ / www.eldiario.es/economia/Parlamento-panameno-Zona-Libre-Colon_0_498000202.html.

El Panamá América. 2016, 20 October. "50.3 toneladas de droga incautadas en lo que va del año." Retrieved from http://www.panamaamerica.com.pa/nacion/503-toneladasde-droga-incautadas-en-lo-que-va-del-ano-1047481.

Fitzgibbon, Will. 2016, 21 November. "Expert committee urges Panama to reform financial services industry." Retrieved from https://panamapapers.icij.org/blog/20161121-panama-experts-committee-report.html.

Gandásegui, Marco A. 2010. "Panamá 2009: elecciones, crisis mundial y movimientos sociales." Revista de Ciencia Política 30(2): 419-437.

Guevara Mann, Carlos. 2008. "Panamá 2007: crecimiento económico, combustión social y catalepsia institucional." Revista de Ciencia Política 28(1): 305-328.

Guevara Mann . 2016. "Panamá: luces y sombras en torno a la institucionalidad democrática." Revista de Ciencia Política 36(1): 259-285.

Gobierno de la República de Panamá. 2016, 29 April. “Presidente Varela instala Comité Independiente que evaluará prácticas del sistema financiero de Panamá." Retrieved from https:/ / www.presidencia.gob.pa/Comunicados / Presidente-Varela-instala-Comite-Independiente-que-evaluara-practicas-del-sistema-financiero-de-Panama.

Gobierno de la República de Panamá. 201622 August. "Gobierno y autoridades indígenas tradicionales firman acuerdo sobre proyecto hidroeléctrico Barro Blanco." Retrieved from https://www.presidencia.gob.pa/Noticias/Gobierno-y-autoridades-indigenas-tradicionales-firman-acuerdo-sobre-proyecto-hidroelectrico-Barro-Blanco-.

Guía, Angel López. 2015, 19 June. “Víctor Benavides renuncia a la Corte Suprema de Justicia." La Prensa. Retrieved from http://www.prensa.com/judiciales/Victor-Benavides-Corte-Suprema-Justicia_0_4235576603.html

Guía, Angel López. 2016, 18 February. "En enero cerraron 55 empresas de la Zona Libre de Colón." La Prensa. Retrieved from http://www.prensa.com/economia/Cierran-Libre-Colon-Asociacion-Usuarios_0_4418558247.html.

Guía, Angel López. 2016, 5 May. "Presidente Varela acepta renuncia de ministro y viceministro de seguridad." La Prensa. Retrieved from http://www.prensa.com/politica/ Presidente-Varela-renuncia-viceministro-Seguridad_0_4476302438.html.

International Consortium of Investigative Journalists [ICIJ]. n.d. "The Panama Papers: Politicians, Criminals and the Rogue Industry That Hides Their Cash." Retrieved from https://panamapapers.icij.org/. 
Justice, Adam. 2016, 5 April. “Panama Papers: President Juan Carlos Varela Defends Transparency." International Business Times. Retrieved from http://www.ibtimes.co.uk/ panama-papers-president-juan-carlos-varela-defends-transparency-1553204.

Koehler-Geib, Friederike, Kinnon Scott, Ayat Soliman and J. Humberto Lopez. 2015. Panama: Locking in Success. Systematic Country Diagnostic. Washington: World Bank.

La Crítica. 2015, 13 November. "Arrestan a 13 funcionarios del Órgano Judicial." Retrieved from http://www.critica.com.pa/nacional/arrestan-13-funcionarios-del-organo-judicial412068.

La Estrella de Panamá, 2015, 21 December. "Asamblea ratifica a dos nuevos magistrados de la Corte Suprema." Retrieved from http://elsiglo.com.pa/panama/asamblearatifica-nuevos-magistrados-corte-suprema/23911389.

La Estrella de Panamá. 2016, 22 December. "Policía Nacional: los homicidios en el 2016 disminuyeron." Retrieved http://laestrella.com.pa/panama/nacional/informa-2016-redujeron-homicidios/23977553.

La Prensa. 2015, 5 March “Moncada Luna, a prisión por la comisión de dos delitos." Retrieved from http://www.prensa.com/judiciales/Moncada-Luna-obligado-comparecer_0_4156084472.html.

La Prensa. 2016, 14 January. “Magistrado Harry Díaz confiesa injerencia de Ricardo Martinelli en la corte." Retrieved from http://www.prensa.com/judiciales/Magistrado-Harry-Ricardo-Martinelli-Corte_0_4392310870.html.

La Prensa. 2016, 25 February. "Ministro de Comercio: "Zona Libre de Colon esta en Cuidados Intensivos." Retrieved from http://www.prensa.com/economia/Ministro-Comercio-Zona-Libre-Colon_0_4423807697.html.

La Prensa . 2016, 18 May. "OECD aplaude paso de Panamá." Retrieved from http://www. prensa.com/mundo/OCDE-aplaude-paso-Panama_0_4485301605.html.

La Prensa. 2016, 25 July. "En Panamá se establece nueva 'Fuerza Especial Antinarcóticos.'” Retrieved from http://www.prensa.com/sociedad/Panama-establece-Fuerza-Especial-Antinarcoticos_0_4537046304.html.

La Prensa. 2016, 17 September. "Congreso General Ngäbe Buglé rechaza acuerdo de Barro Blanco." Retrieved from http://www.prensa.com/provincias/Congreso-General-Bugle-Barro-Blanco_0_4577542238.html.

León, Guadalupe. 2016, 18 September. "Congreso indígena rechazan acuerdo de Barro Blanco." La Estrella de Panamá. Retrieved from http://laestrella.com.pa/panama/nacional/congreso-indigena-rechazan-acuerdo-barro-blanco/23961615.

Luna, Clara Inés and Salvador Sánchez. 2009. "Panamá: paraíso imperfecto." Revista de Ciencia Política 29(2): 533-564.

Mendoza, Eduardo. 2016, 11 August. "Banda alteraba condenas judiciales." La Prensa. Retrieved from http://www.prensa.com/politica/Henriquez-caido_0_4549045153. html.

Ministerio de Economía y Finanzas (MEF). 2016. “Informe Económico y Social - Primer trimestre 2016." Dirección de Análisis Económico y Social. Retrieved from http:/ /www. mef.gob.pa/es/informes/Documents/Informe\%20Economico\%20y\%20Social\%20 -\%20Marzo\%202016.pdf.

Molina, Thabata. 2016, 24 April. "Panamá mantiene la esperanza de que Venezuela pague su deuda." PanamPost. Retrieved from https://es.panampost.com/thabata-molina/2016/04/24/panama-mantiene-la-esperanza-de-que-venezuela-pague-su-deu$\mathrm{da} /$.

Moreno, Quintin. 2016, 4 January. “Presidente Varela juramenta a nuevos magistrados Russo y Cedalise." La Estrella de Panamá. Retrieved from http:/ /laestrella.com.pa/panama/ politica/presidente-varela-juramenta-nuevos-magistrados-russo-cedalise/23913865.

Nava, Elaine. 2016, 21 December. "MEF vuelve a bajar las perspectivas de crecimiento para 2016." Panamá Today. Retrieved from http://www.panamatoday.com/es/economy/ mef-vuelve-bajar-las-perspectivas-de-crecimiento-para-2016-2956. 
OECD. 2016a. "Statement from OECD Secretary-General Angel Gurría on the 'Panama Papers.'" Retrieved from http://www.oecd.org/newsroom/statement-from-oecd-secretary-general-angel-gurria-on-the-panama-papers.htm.

OECD. 2016b. "Secretary-General Report to G20 Finance Ministers Shanghai, PRC, 26-27 February 2016." Retrieved from https://www.oecd.org/g20/topics/taxation/oecd-secretary-general-tax-report-g20-finance-ministers-february-2016.PDF.

Oficina de las Naciones Unidas para la Droga y el Delito [UNODC]. 2016. "Colombia: Monitoreo de territorios afectados por cultivos ilícitos, 2015." UNODC Colombia. Retrieved from http://www.unodc.org/documents/cropmonitoring/Colombia/Monitoreo_ Cultivos_ilicitos_2015.pdf.

Pérez, Antonio. 2016, 5 April. "La telaraña compleja de la firma poderosa e influyente." El Panamá América. Retrieved from http://www.panamaamerica.com.pa/tema-deldia/la-telarana-compleja-de-la-firma-poderosa-e-influyente-1020685.

Pérez, Orlando J. 2011. Political Culture in Panama: Democracy After Invasion. New York: Palgrave Macmillan.

Pérez, Orlando J. 2017. "Panama: The Preeminence of Geography and the Transit Route for Establishing Panama's Strategic Culture." In Culture and National Security in the Americas, edited by Eduardo Gamarra and Brian Fonseca. Lanham: Lexington Books.

PMC Asset Management. 2016. "Panama Canal will increase contribution to the state of \$600 million in 2017." Retrieved from http:/ / www.pmcassetmanagementcorp.com/panama-canal-will-increase-contribution-to-the-state-of-600-million-in-2017/.

Prieto-Barreiro, Ereida. 2015, 19 August. “El coleccionista de casas," La Prensa. 14 de abril. http://www.prensa.com/locales/coleccionista-casas_0_4185331634.html.

Red Latinoamericana para la Transparencia Legislativa. 2016. "Índice Latinoamericano de transparencia legislativa". Retrieved from http://indice.transparencialegislativa. org/.

Reuters. 2016, 6 August. “Nobel Economist Stiglitz Quits Panama Papers Probe over 'Lack of Transparency.'" The Telegraph. Retrieved from http://www.telegraph.co.uk/ news /2016/08/06/nobel-economist-stiglitz-quits-panama-papers-probe-over-lackof/.

Sanz, José Antonio. 2016, 13 September. "Panama and Colombia Maintain Tariff Dispute: A Long-distance Race." Panamá Today. Retrieved from http:/ / www.panamatoday.com/ economy/panama-and-colombia-maintain-tariff-dispute-long-distance-race-1577.

Schmidt, Blake. 2017, 21 March. "Trump Ally Battles Extradition to Panama from Miami." Bloomberg. Retrieved from https://www.bloomberg.com/news/articles/2017-03-21/a-panama-ex-president-fights-extradition-from-miami-exile.

Schwab, Klaus. 2016. The Global Competitiveness Report 2016-2017. Geneva: World Economic Forum.

Semana. 2016, 9 May. "6.000 personas que trabajan para la familia Waked se podrían ver en riesgo." Retrieved from http:/ / www.semana.com/mundo/articulo/trabajadores-delas-empresas-de-los-waked-podrian-verse-en-riesgo/472987.

Transparency International. 2017. "Corruption Perceptions Index 2016: Results." Retrieved from https://www.transparency.org/news/feature/corruption_perceptions_index_2016.

United Nations Office on Drugs and Crime. 2016. "UNODC supporting Criminal Procedure Reform in Panama." Retrieved from https://www.unodc.org/unodc/en/frontpage/2016/June/unodc-supporting-criminal-procedure-reform-in-panama.html.

Varela, Juan Carlos. 2016, 3 May. "Remarks: President of Panama Juan Carlos Varela at 46th Annual Washington Conference of the Americas." Americas Society/Council of the Americas. Retrieved from http://www.as-coa.org/articles/remarks-president-panamajuan-carlos-varela-46th-annual-washington-conference-americas.

Wilkinson, Tracy. 2015, 23 May. "In Panama, Corruption Inquiries Grow after President's Tenure Ends." The Los Angeles Times. Retrieved from http:/ / www.latimes.com/world/ mexico-americas/la-fg-panama-corruption-20150523-story.html\#page=1. 
Wolters Kluwer NZ. 2016, 20 April. “OECD Secretary-General issues statement on 'Panama Papers."” Retrieved from http://www.wolterskluwer.co.nz/oecd-secretary-general-issues-statement-panama-papers/.

World Bank. 2016. "Panama Overview." Retrieved from http://www.worldbank.org/en/ country/panama/overview.

Orlando J. Pérez is Associate Dean, College of Arts, Humanities and Social Sciences, Millersville University of Pennsylvania. He received his M.A. and Ph.D. in political science from the University of Pittsburgh. As a consultant, he has worked on public opinion surveys, democratization, civilmilitary relations, and anti-corruption issues for the United States Agency for International Development (USAID) and the UN Development Program (UNDP). He is the author of CivilMilitary Relations in Post-Conflict Societies: Transforming the Role of the Military in Central America (Routledge, 2015); The Historical Dictionary of El Salvador (Rowman \& Littlefield, 2016); Political Culture in Panama: Democracy after Invasion (Palgrave-Macmillan, 2011); and co-editor (with Richard Millett and Jennifer Holmes) of Latin American Democracy: Emerging Reality or Endangered Species? (Routledge, 2015). He serves as coordinator for Panama and Honduras for the Americas Barometer survey of the Latin American Public Opinion Project (LAPOP) at Vanderbilt University. 
- 